\title{
Pengaruh Tipe Industri, Ukuran Perusahaan, Latar Belakang Komite Audit, Intensitas Goodwill, dan Kualitas Audit Terhadap Kepatuhan Pengungkapan Goodwill Impairment Testing
}

\author{
Maudhita Cyrena \\ Universitas Katolik Soegijapranata Semarang \\ carencyr@gmail.com
}

\begin{abstract}
The purpose of this study is to examine the effect of industrial type, company size, audit committee background, intensity of goodwill, and auditor quality on the disclosure of goodwill impairment testing compliance of firms listed on Indonesia Stock Exchange in the period of 2013-2017. It argues that manufacturing companies have higher operational complexity relative to other type of industry and thus disclose more information regarding firm's activities, including information on goodwill impairment testing compliance. The results support the prediction. With regard to firm size, goodwill intensity, and auditor quality, the hypoyheses predict that these variables are positively associated with goodwill impairment testing compliance. The resultus support these predictions. Meanwhile, audit committee's background has no effect on the disclosure of goodwill impairment testing compliance.
\end{abstract}

Keywords: Goodwill, Impairment testing, Goodwill Intensity, and Auditor Quality

\begin{abstract}
Abstrak
Penelitian ini bertujuan untuk mengetahui pengaruh tipe industri, ukuran perusahaan, latar belakang komite audit, intensitas goodwill, dan kualitas auditor terhadap kepatuhan pengungkapan goodwill impairment testing pada perusahaan yang terdaftar di Bursa Efek Indonesia tahun 2013-2017. Tipe industri diprediksi mempengaruhi pengungkapan goodwill impairment testing karena perusahaan yang masuk kelompok industri manufaktur beroperasi dalam industri yang kompleks sehingga harus mengungkapkan lebih banyak informasi dibanding tipe industri lain, termasuk informasi tentang pengungkapan goodwill impairment testing. Ukuran perusahaan, intensitas goodwill, dan kualitas audit diprediksi berpengaruh positif terhadap kepatuhan pengungkapan goodwill impairment testing. Hasil pengujian juga mendukung prediksi tersebut. Sementara itu, Latar belakang komite audit tidak berpengaruh terhadap kepatuhan pengungkapan goodwill impairment testing.
\end{abstract}

Kata kunci : Goodwill, Impairment testing, Intensitas Goodwill, dan Kualitas Auditor

\section{PENDAHULUAN}

Menurut PSAK 48 (revisi 2014) perusahaan harus menilai apakah terdapat indikasi aset mengalami penurunan nilai. Jika terdapat indikasi bahwa aset mengalami penurunan nilai, perusahaan harus melakukan estimasi jumlah terpulihkan aset tersebut. Namun untuk aset tidak berwujud dikatakan bahwa perusahaan harus melakukan pengujian penilaian aset tanpa pempertimbangkan apakah ada indikasi penurunan nilai. Entitas harus menguji penurunan nilai aset tidak berwujud dengan masa manfaat takterbatas atau aset berwujud yang belum 
dapat digunakan, termasuk penurunan nilai goodwill. Goodwill adalah aset tak berwujud yang diperoleh dari selisih lebih antara harga perolehan dan nilai wajar aset bersih entitasnya pada saat akuisisi. Goodwill harus dinilai kewajarannya setiap tahun melalui uji penurunan nilai goodwill.

Pengujian penurunan nilai goodwill adalah salah satu hal yang sulit diestimasi dan diukur dari peralihan perubahan standar akuntansi. Pengungkapan penurunan goodwill merupakan topik yang menarik dan telah banyak diteliti (Bepari dan Mollik (2015; Aryantisari (2018). Dalam penelitian Bepari dan Mollik (2015), kualitas audit dan latar belakang komite audit berpengaruh merupakan faktor penting yang mempengaruhi kepatuhan pengungkapan pengujian penurunan goodwill.

Kualitas audit sering dikaitkan dengan kepatuhan pengungkapan pengujian penurunan goodwill. Salah satu ukuran kualitas audit yang banyak digunakan dalam penelitian empiris di Indonesia adalah apakah kantor akuntan lokal memiliki afiliasi dengan KAP Big 4. KAP Big 4 diyakini lebih mendorong perusahaan untuk lebih traspran dalam aktivitas yang dilakuka, termasuk dalam mengungkapkan pengujian penurunan goodwill (Bepari dan Mollik, 2015). Perusahaan Big 4 akan menerapkan kepatuhan IFRS 4 lebih ketat dalam mengaudit laporan keuangan perusahaan. Pengelolaan perusahaan yang baik lebih bisa mengarahkan perusahaannya untuk melaporkan laporan keuangannya berdasarkan peraturan IFRS.

Komite audit juga berperan penting kepatuhan pengungkapan pengujian penurunan goodwill (Aryantisari (2018). Salah satu fungsi Komite Audit yaitu menjaga kredibilitas laporan keuangan dengan memastikan penerapan kebijakan akuntansi yang sehat dan konsisten. Agar dapat melakukan fungsi tersebut secara efektif, Komite Audit selayaknya memiliki latar belakan akuntansi atau keuangan sehingga dapat mendorong perusahaan untuk lebih tranparan dalam melaporkan aktivitas bisnis dan keuangan, termasuk mengungkapkan pengujian penurunan nilai goodwill.

Perusahaan dengan tingkat intensitas goodwill yang tinggi juga diprediksi akan memiliki tingkat kepatuhan yang lebih tinggi dalam mengungkapkan pengujian penurunan nilai goodwill. Hasil dari penelitian Bepari et al., (2014) membuktikan bahwa intensitas goodwill berpengaruh positif terhadap kepatuhan perusahaan dalam mengungkapkan pengujian penurunan nilai goodwill. Di samping itu, tipe perusahaan juga berhubungan dengan tingkat kepatuhan perusahaan dalam pengungkapan pengujian penurunan nilai goodwill. Bepari et al., (2014) membuktikan bahwa tipe perusahaan berpengaruh positif terhadap tingkat kepatuhan pengungkapan goodwill impairment testing.

Penelitian ini menguji kembali faktor-faktor yang telah teridentifikasi dalam Bepari et al. (2014), Bepari dan Mollik (2015), dan Aryantisari (2018) dengan menambah variabel ukuran perusahaan (size) dan tingkat hutang (leverage). Tujuannya adalah untuk menilai validitas eksternal hasil-hasil penelitian sebelumnya dan menguji pengaruh ukuran perusahaan dan tingkat utang terhadap kepatuhan pengungkapan pengujian penurunan goodwill .

\section{TINJAUAN LITERATUR DAN PERUMUSAN HIPOTESIS}

\section{Teori Keagenan (Agency Theory)}

Teori keagenan yang membahas tentang hubungan manajemen sebagai agen dan pemegang saham sebagai prinsipal. Prinsipal yang menyediakan dana dan fasilitas untuk menjalankan perusahaan. Selain itu, manajemen memiliki kewajiban dalam mengelola amanah yang diberikan oleh pemegang saham. Agen diwajibkan untuk memberikan laporan periodik kepada prinsipal mengenai usaha yang dijalankannya. Prinsipal akan menilai kinerja agen melalui laporan keuangan yang disampaikan kepada prinsipal Purwandari (2012). Maka 
dari itu, perusahaan diminta untuk melakukan pengungkapan informasi keuangan dan informasi yang bersangkutan lainnya dalam laporan keuangan tahunan karena pengungkapan sebagai aspek penting akuntansi keuangan.

Dalam Nuryani (2014) dikatakan bahwa standar akuntansi yang berubah dalam menghapuskan amortisasi goodwill diduga mempunyai fleksibilitas yang memberi celah manajemen untuk melaporkan penurunan nilai goodwill dengan memakai keputusan pribadinya sendiri. Tidak adanya nilai pasar goodwill yang pasti dapat memperkuat manajemen (agent) dalam memanfaatkan keadaan tersebut pada saat mengatur laba yang akan dilaporkan.

\section{Teori Persinyalan (Signalling Theory)}

Teori signaling mengemukakan bahwa perusahaan yang memiliki kualitas baik akan memberikan sinyal pada pengguna laporan keuangan, maka dari itu pengguna laporan keuangan diminta dapat membedakan perusahaan yang memiliki kualitas baik dan buruk (Hartono, 2005) dalam Estrini (2013). Supaya sinyal terbilang baik maka pasar harus menangkap dan memahami dengan baik agar tidak ditiru oleh perusahaan yang mempunyai kualitas yang buruk. Sinyal ini berupa informasi tentang apa yang telah dilakukan oleh manajemen untuk merealisasikan keingan pemilik.

Perusahaan mengeluarkan semua informasi yang sangat penting untuk pengambilan keputusan investasi pihak diluar perusahaan (Nuryani dan Samsudiono, 2014). Para pengguna informasi akan mengkaji informasi yang mereka dapatkan sebagai sinyal baik (good news) dan sinyal buruk (bad news). Perusahaan yang mengungkapkan laporan keuangan yang memiliki sinyal baik atau kepada pasar diharapkan pasar dapat menjadi informasi yang penting untuk pengambilan keputusan untuk berinvestasi. Sinyal yang diberikan pasar kepada publik akan mempengaruhi harga saham perusahaan.

Perusahaan yang mengungkapkan goodwill impairment test akan memberikan sinyal terhadap pengguna laporan keuangan, terutama kepada investor yang memungkinkan arus kas di masa depan akan mengalami kenaikan atau penurunan. Pada saat arus kas mengalami kenaikan atau penurunan akan mempengaruhi kemampuan perusahaan dalam menghasilkan keuntungan di masa depan. Perusahaan yang melaporkan goodwill impairment test akan memberikan informasi yang memungkinkan perusahaan itu baik atau buruk di masa depan.

\section{Goodwill}

Goodwill yang diakui di dalam kombinasi bisnis adalah aset yang memiliki manfaat ekonomi di masa depan yang muncul dari aset lain yang terdapat dalam kombinasi bisnis yang tidak dikenali secara individual dan diakui secara terpisah. Goodwill diatur dalam tiga PSAK yaitu PSAK 19 (Aset Tak Berwujud), PSAK 22 (Kombinasi Bisnis), dan PSAK 48 (Penurunan Nilai Aset). Goodwill adalah perbedaan antara biaya perolehan dengan nilai wajar aset neto yang dapat dikenali dari perusahaan yang telah diakuisisi.

Goodwill akan muncul pada saat perusahaan melakukan akuisisi perusahaan lain secara keseluruhan. Nilai goodwill didapatkan dari biaya untuk melakukan akuisisi dikurangi dengan nilai pasar wajar aset berwujud, aset tak berwujud yang bisa diidentifikasi, dan kewajiban yang didapat dalam akuisisi. Goodwill bisa disebut sebagai keunggulan atau kelebihan karena perusahaan telah memiliki reputasi yang baik.

\section{Goodwill Impairment Testing}

Dalam PSAK 48 (2012) menyatakan bahwa goodwill tidak lagi menggunakan metode amortisasi, namun menggunakan pengujian penurunan nilai (impairment test) pada setiap tahunnya. PSAK 48 (2012) mengungkapkan goodwill diperoleh dalam kombinasi bisnis sejak 
tanggal akuisisi harus dialokasikan pada unit penghasil kas yang diharapkan bisa memberi manfaat melalui kegiatan kombinasi bisnis tersebut.

Goodwill yang diperoleh harus dialokasikan kepada setiap unit penghasil kas (UPK) phak pengakuisisi karena goodwill tidak menghasilkan aliran kas sendiri. Unit penghasil kas merupakan kelompok terkecil aset yang teridentifikasi menghasilkan arus kas masuk dari penggunanya dimana arus kas tersebut tidak bergantung pada arus kas yang masuk dari aset ataupun kelompok aset lain. Unit penghasil kas yang mendapatkan bagian goodwill harus melakukan uji perununan nilai setiap tahunnya. Pengujian penurunan nilai goodwill (goodwill impairment testing) diperusahaan diharuskan memastikan nilai terpulihkan goodwill. Apabila jumlah terpulihkan melebihi jumlah yang tercatat unit dan goodwill yang dialokasikan ke unit tersebut dianggap tidak terjadi penurunan.

\section{Intensitas Goodwill}

Intensitas goodwill adalah besar atau kecilnya presentase dari goodwill di suatu perusahaan. Maka, perusahaan yang memiliki jumlah goodwill yang besar lebih berpotensi dalam pengungkapan goodwill impairment test. Menurut Aryantisari (2018) pada saat perusahaan mengalami kerugian penurunan nilai, perusahaan cenderung tidak mempermasalahkan hal tersebut karena masih memiliki goodwill yang cukup besar. Namun, perusahaan yang memiliki jumlah goodwill yang kecil, perusahaan tersebut akan ragu untuk melakukan pengungkapan goodwill impairment testing. Dalam hal ini intensitas goodwill berdampak pada kepatuhan perusahaan dalam mengungkapkan goodwill impairment testing.

\section{Tipe Industri}

Tipe industri adalah kategori perusahaan berdasarkan dari jenisnya (Aprisa, 2016). Perusahaan akan di kelompokkan berdasarkan suatu kesamaan tertentu. Karakteristik industri yang berbeda - beda dapat menyebabkan perbedaan kompleksitas dalam pengungkapan pelaporan keuangan. Karakteristik perusahaan yang dimiliki perusahaan berkaitan dengan bidanag usaha, risiko usaha, karyawan yang dimiliki, dan lingkungan perusahaan tersebut. Tipe industri dibagi menjadi dua jenis yaitu perusahaan manufaktur dan perusahaan non manufaktur. Perusahaan manufaktur merupakan badan usaha yang mempunyai aktivitas material atau bahan mentah hingga menjadi barang jadi dan langsung dijual kepada konsumennya. Di dalam perusahaan manufaktur mengungkaPerusahaan non manufaktur terdiri dari perusahaan dagang, jasa, dan perusahaan perseorangan. Menurut Cooke (1992) Perusahaan manufaktur akan melaporkan lebih banyak informasi dari pada jenis industri lainnya. Perluasaan informasi ini sangat berpengaruh terhadap pengungkapan pelaporan keuangan termasuk mengungkapkan goodwill impairment testing.

\section{Ukuran Perusahaan ( Size )}

Besar ukuran perusahaan dapat diketahui melalui total aset, penjualan dan pemegang saham (Sudarmadji dan Sularto, 2007). Semakin besar total aset, investasi dan penjualan maka semakin besar perusahaan tersebut. Perusahaan besar juga memiliki manajemen yang lebih baik dalam mengelola perusahaan dan berkemampuan menghasilkan laporan keuangan yang berkualitas. Menurut Cooke (1989) perusahaan besar mempunyai biaya informasi yang lebih rendah, perusahaan besar memiliki kompleksitas dan dasar kepemilikan yang lebih luas daripada perusahaan kecil. Menurut Nasution dan Setiawan (2007) dalam (Yunizar, 2014) perusahaan besar mempunyai tuntutan yang besar dalam menyediakan informasi bagi pelanggan, pemasol, analisis, dan masyarakat mereka akan lebih berhati - hati dalam melakukan pelaporan keuangan, maka berdampak perusahaan akan melaporkan kondisinya lebih akurat. Semakin besar jumlah pemegang saham yang membutuhkan informasi, semakin rinci dalam hal pengungkapan pelaporan keuangan. Maka dari itu perusahaan akan berusaha 
untuk mengungkapkan laporan keuangannya sesuai dengan standar yang berlaku, perusahaan juga harus mengungkapkan goodwill impairment testing.

\section{Latar Belakang Komite Audit}

Menurut Suaryana (2005) komite audit bertugas membantu dewan komisaris untuk melakukan pengawasan atas pelaporan keuangan untuk meningkatkan kredibilitas laporan keuangan. Komite audit juga bertugas menalaah kebijakan akuntansi yang diterapkan dalam perusahaan, memeriksa sistem pelaporan eksternal, menilai pengendalian internal dan kepatuhan terhadap peraturan yang digunakan dalam perusahaan. Agar komite audit bisa melaksanakan tugasnya dengan benar diperlukan kualifikasi - kualifikasi khusus yang memadai supaya dapat menjalankan tugas dan tanggung jawab secara maksimal. Bepari dan Mollik (2015) menyatakan perusahaan yang memiliki komite audit dengan latar belakang memiliki pengetahuan tentang akuntansi atau keuangan, akan dapat lebih memperbaiki kualitas laporan keuangan. Komite audit yang tidak memiliki pemahaman tentang akuntansi ataupun keuangan akan mengalami kesulitan dalam menelaah pengungkapan laporan keuangan dalam perusahaan karena tidak paham standar - standar akuntansi yang berlaku

\section{Kualitas Auditor}

Menurut DeAngelo (1981) kualitas auditor adalah probabilitas bahwa auditor tidak akan melaporkan laporan audit dengan opini wajar tanpa pengecualian untuk laporan keuangan laporan keuangan yang memuat kekeliruan material. Kualitas audit juga dapat diukur dari ketepatan informasi yang dilaporkan oleh auditor. Laporan keuangan menjadi bentuk pertanggung jawaban dari manajemen kepada investor dan pemegang saham yang harus mempunyai informasi yang dipercaya oleh semua pihak. Jika terjadi manipulasi terhadap laporan keuangan bisa menurunkan kualitas informasi akuntansi dan dapat menghilangkan kepercayaan berbagai pihak. Maka dari itu perusahaan akan memilih auditor yang terbaik untuk mengaudit laporan keuangan dengan teliti, sehingga dapat mengurangi manipulasi atau kecurangan dalam laporan keuangan. Kualitas auditor juga merupakan nama baik atau citra yang didapatkan atas kerja yang baik dan kepercayaan dari para kliennya dalam tangggung jawab sebagai auditor.

Menurut Kantor Akuntan Publik (KAP) atau disebut juga Big-4 akan berupaya menyajikan kualitas audit yang lebih besar dibandingkan dengan KAP yang kecil atau nonBig4. DeAngelo (1981) menyatakan auditor Big-4 juga memiliki reputasi yang melebihi nonBig4, apabila auditor Big-4 memberikan opini audit yang salah maka memberikan dampak yang lebih besar dalam kehilangan klien. Oleh karena itu auditor Big-4 memiliki kualitas auditor yang lebih tinggi dibandingkan dengan non-Big4.

\section{Perumusan Hipotesis}

\section{Tipe Industri dan Pengungkapan Goodwill Impairment Testing}

Tipe industri merupakan karakteristik suatu perusahaan yang mempengaruhi dalam pengungkapan pelaporan keuangan. Cooke (1992) menyatakan bahwa luas pengungkapan dalam laporan tahunan mungkin tidak sama untuk semua sektor ekonomi. Menurut penelitian Cooke (1992) perusahaan manufaktur lebih banyak melaporkan informasi dibandingkan dengan perusahaan lain karena perusahaan manufaktur memiliki kompleksitas yang berbeda dengan industri pada umumnya. Kompleksitas timbul karena setiap industri mengungkapkan informasi akuntansi secara berbeda sehingga masing-masing industri akan memiliki kelengkapan laporan keuangan yang berbeda. Cooke (1992) dan Bepari dan Mollik (2015) memberi bukti bahwa tipe industri berpengaruh positif terhadap kepatuhan pengungkapan goodwill impairment testing. 
Berdasarkan pemikiran ini, hubungan tipe industri dan kepatuhan pengungkapan goodwill impairment testing dinyatakan dalam hipotesis berikut:

\section{$\mathrm{H}_{1}$ : Tipe industri berpengaruh positif terhadap kepatuhan pengungkapan goodwill impairment testing.}

\section{Kualitas Auditor dan Pengungkapann Goodwill Impairment Testing}

Menurut DeAngelo (1981) auditor Big 4 memiliki reputasi yang lebih baik dibandingkan dengan auditor non-Big4. Auditor Big 4 akan lebih sensitif dibandingkan dengan auditor nonBig 4 dalam hal mengaudit laporan keuangan karena auditor Big 4 akan lebih banyak kehilangan klien jika mereka salah melaporkan dan dalam memberikan opini. Perusahaan dengan auditor Big 4 akan mengungkapkan laporan keuangan sesuai dengan standar yang berlaku, begitu juga dalam pengungkapan goodwill impairment testing. Untuk menjaga dan meningkatkan kredibilitas laporan keuangan, auditor Big 4 akan mendorong perusahaan mengungkapkan goodwill impairment testing. Auditor Big 4 akan meminta perusahaan untuk lebih transparan dalam mengungkapkan goodwill impairment testing dan juga tidak menyembunyikan sesuatu hal yang dapat merugikan perusahaan.

Berdasarkan pemikiran ini, hubungan kualitas auditor dan kepatuhan pengungkapan goodwill impairment testing dinyatakan dalam hipotesis berikut:

$\mathrm{H}_{2}$ : Kualitas auditor berpengaruh positif terhadap kepatuhan pengungkapan goodwill impairment testing.

\section{Latar Belakang Komite Audit dan Pengungkapan goodwill impairment Testing}

Pembentukan komite audit sebagai salah satu komite khusus di dalam perusahaan yang berfungsi untuk mengoptimalkan pengawasan yang merupakan tanggung jawab dewan komisaris. Anggota komite audit sebaiknya memiliki latar belakang akuntansi atau keuangan dalam melakukan pengawasan laporan 25 keuangan. Hal tersebut sangat penting karena mempengaruhi efektivitas dan kinerja komite audit di perusahaan. Pada saat komite audit mempunyai latar belakang akuntansi atau keuangan, komite audit akan lebih memahami kinerja operasi dalam suatu perusahaan. Pengawasan laporan keuangan akan lebih ketat ketika Komite Audit memiliki latar belakang akuntansi atau keuangan dan memahami standar akuntansi yang terkait, baik standar baru ataupun standar lama. Komite Audit akan lebih ketat mengawasi pengungkapan laporan keuangan suatu perusahaan, termasuk pengungkapan goodwill impairment testing. Komite Audit yang menjalankan fungsinya secara efektif selalu berupaya mendorong perusahaan agar lebih transparan dalam melaporkan transaksi atau peristiwa ekonomi yang dialami perusahaan, termasuk pengungkapan goodwill impairment testing.

Berdasarkan pemikiran ini, hubungan latar belakang Komite Audit dan kepatuhan pengungkapan goodwill impairment testing dinyatakan dalam hipotesis berikut:

\section{$\mathrm{H}_{3}$ : Latar belakang komite audit berpengaruh positif terhadap pengungkapan goodwill impairment testing.}

\section{Intensitas Goodwill dan Kepatuhan Pengungkapan Goodwill Impairment Testing}

Perusahaan yang memiliki intensitas goodwill yang cukup tinggi akan lebih besar kemungkinannya mengalami penurunan nilai dibandingkan perusahaan yang tidak memiliki intensitas goodwill yang tinggi. Hal ini tidak terlepas dari kesulitan yang dialami perusahaan untuk mempertahankan nilai goodwill yang besar yang timbul dari akuisisi perusahaan. Nilai goodwill yang kecil lebih mudah dipertahankan sehingga kecil kemungkinannya mengalami penurunan nilai. Intensitas goodwill diartikan sebagai persentase goodwill atas aset 
perusahaan. Penelitian Bepari et al., (2014) pada perusahaan-perusahaan di Australia mendapatkan hubungan positif antara tingkat kepatuhan perusahaan terhadap goodwill impairment testing dengan intensitas goodwill dan juga penelitian Petersen dan Plenborg (2010) memberi bukti bahwa intensitas goodwill berpengaruh positif terhadap kepatuhan IFRS goodwill impairment testing. Berdasarkan hasil argumen teori dan penelitian terdahulu maka hubungan antara intensitas goodwill dan goodwill impairment testing dinyatakan dalam hipotesis berikut ini :

\section{$\mathrm{H}_{4}$ : Intensitas goodwill perusahaan berpengaruh positif terhadap kepatuhan pengungkapan goodwill impairment testing.}

\section{Ukuran Perusahaan dan Pengungkapan Goodwill Impairment Testing}

Menurut Sujianto (2001) ukuran perusahaan dideskripsikan sebagai besar kecilnya suatu perusahaan yang ditetapkan oleh total aset, jumlah penjualan, rata-rata total penjualan, rata rata total aset, dan jumlah pemegang saham. Perusahaan besar mempunyai tingkat asimetri informasi yang rendah dan tingkat kapasitas organisasi yang lebih tinggi dibandingkan perusahaan kecil sehingga perusahaan besar lebih terdorong untuk mematuhi standar akuntansi dibandingkan dengan perusahaan kecil, termasuk pengungkapan penurunan nilai goodwill (Aryantisari, 2018). Perusahaan yang berukuran besar cenderung lebih banyak mengungkapkan bagian-bagian laporan keuangannya karena mereka memiliki lebih banyak informasi yang diungkapkan. Perusahaan besar akan lebih hati-hati dalam melakukan pengelolaan perusahaan karena perusahaan yang lebih besar diperhatikan oleh masyarakat sehingga perusahaan akan melaporkan dengan akurat. Berdasarkan hasil penelitian di atas, maka hipotesis dalam penelitian ini :

\section{$\mathrm{H}_{5}$ : Ukuran perusahaan berpengaruh positif terhadap kepatuhan pengungkapan goodwill impairment testing.}

\section{METODA PENELITIAN}

\section{Populasi dan Sampel}

Penelitian ini menggunakan jenis data sekunder dengan populasi perusahaan yang terdaftar di dalam Bursa Efek Indonesia tahun 2013 - 2017. Sumber data menggunakan annual report perusahaan yang terdapat di situs web Bursa Efek Indonesia (BEI) atau IDX (www.idx.co.id) dan situs web dari masing-masing perusahaan. Sampel adalah bagian dari populasi yang menjadi perhatian peneliti (Butar Butar, 2007). Metode yang digunakan untuk pengambilan sampel adalah metode purposive sampling, yaitu pengambilan sampel dari populasi berdasarkan kriteria tertentu. Kriteria sampel yang digunakan antara lain sebagai berikut :

1. Perusahaan terdaftar di Bursa Efek Indonesia pada tahun 2013 - 2017.

2. Perusahaan yang mengakuisisi perusahaan lain sehingga memiliki goodwill.

3. Perusahaan yang memiliki mata uang rupiah dalam laporan keuangan.

4. Memiliki data laporan keuangan dan annual report secara lengkap.

Berdasarkan kriteria pengambilan sampel diatas, maka sampel dalam penelitian ini dapat dilihat pada Tabel 1. Jumlah sampel perusahaan yang dapat digunakan dalam pengujian hipotesis sebanyak 436 observasi perusahaan. Jumlah ini relatif sedikit dibanding perusahaan yang terdaftar di BEI. Ini diakibatkan banyaknya perusahaan yang harus dikeluarkan dari sampel karena tidak melaporkan good will dalam laporan posisi keungan perusahaan. Ada sebanyak 1778 observasi perusahaan yang harus dikeluarkan. 
Tabel 1. Kriteria Pengambilan Sampel

\begin{tabular}{|l|c|c|c|c|c|c|}
\hline & $\mathbf{2 0 1 3}$ & $\mathbf{2 0 1 4}$ & $\mathbf{2 0 1 5}$ & $\mathbf{2 0 1 6}$ & $\mathbf{2 0 1 7}$ & Total \\
\hline $\begin{array}{l}\text { Perusahaan yang } \\
\text { terdaftar di BEI } \\
\text { tahun 2013 - } \\
2017\end{array}$ & 479 & 479 & 483 & 512 & 555 & 2508 \\
\hline $\begin{array}{l}\text { Perusahaan yang } \\
\text { tidak memiliki } \\
\text { goodwill }\end{array}$ & $(348)$ & $(344)$ & $(341)$ & $(370)$ & $(375)$ & $(1778)$ \\
\hline $\begin{array}{l}\text { Laporan } \\
\text { keuangan yang } \\
\text { tidak } \\
\text { diungkapkan } \\
\text { dalam mata uang } \\
\text { rupiah }\end{array}$ & $(32)$ & $(35)$ & $(33)$ & $(33)$ & $(39)$ & $(172)$ \\
\hline $\begin{array}{l}\text { Laporan } \\
\text { Keuangan dan } \\
\text { laporan tahunan } \\
\text { tidak tersedia } \\
\text { dari sumber data } \\
\text { yang digunakan }\end{array}$ & $(17)$ & $(15)$ & $(18)$ & $(20)$ & $(52)$ & $(122)$ \\
\hline $\begin{array}{l}\text { Jumlah Sampel } \\
\text { Perusahaan }\end{array}$ & 82 & 85 & 91 & 89 & 89 & 436 \\
\hline
\end{tabular}

\section{Jenis dan Sumber Data}

Jenis data yang digunakan dalam penelitian ini memakai data sekunder yang berasal dari laporan tahunan tahun 2013-2017 yang diperoleh dari situs web BEI atau IDX (www.idx.co.id) dan situs web dari masing-masing perusahaan. Data sekunder adalah data penelitian yang didapat peneliti secara tidak langsung melalui media perantara (diperoleh dan dicatat oleh pihak lain). Data penelitian ini merupakan laporan tahunan dan laporan keuangan perusahaan yang terdaftar dalam Bursa Efek Indonesia (BEI) dari tahun 2013-2017.

\section{Pengukuran Variabel}

Variabel kepatuhan pengungkapan goodwill impairment testing diukur menggunakan indeks kepatuhan yang tedapat di dalam penelitian Bepari dan Mollik (2015). Tabel 2 menampilkan item-item yang digunakan untuk menghitung indeks kepatuah pengungkapan goodwill. Metode nilai pakai ( value in use ) merupakan nilai sekarang dari taksiran arus kas yang diharapkan akan diterima atau unit penghasil kas. Sedangkan metode nilai wajar (fair value) merupakan jumlah yang dapat dihasilkan dari penjualan suatu aset atau unit penghasil kas dalam transaksi antara pihak yang mengerti dan berkehendak bebas tanpa tekanan dikurangi biaya pelepasan aset.

Jika didalam laporan keuangan memenuhi kriteria yang ada ditabel (YES) akan diberi poin 1 namun bila tidak memenuhi kriteria yang ada ditabel (NO) maka diberi nilai 0 . Indeks kepatuhan merupakan rasio yang dihitung dengan cara membagi jumlah nilai kepatuhan pengungkapan yang sesungguhya dilakukan oleh perusahaan dengan nilai maksimum yang mampu dicapai oleh perusahaan.

$$
\text { GWIMPRT }=\frac{\Sigma \text { Skor Kepatuhan Pengungkapan bagi Perusahaan }}{\Sigma \text { Skor Maksimum Kriteria Kepatuhan Pengungkapan }}
$$


Tabel 2. Indeks Kepatuhan Pengungkapan

Goodwill Impairment Testing

\begin{tabular}{|c|c|c|c|c|}
\hline NO & Keterangan & $\begin{array}{c}\text { Metode } \\
\text { Value in } \\
\text { Use (VIU) } \\
\end{array}$ & $\begin{array}{c}\text { Metode } \\
\text { Fair Value } \\
\text { (FVM) }\end{array}$ & $\begin{array}{c}\text { Referensi } \\
\text { bagian } \\
\text { PSAK 48 }\end{array}$ \\
\hline 1. & $\begin{array}{l}\text { Pengungkapan yang memiliki } \\
\text { kaitan dengan asumsi penting. }\end{array}$ & Yes & Yes & $\begin{array}{c}\text { Halaman } \\
766 \text { dalam } \\
\text { paragraf } 129\end{array}$ \\
\hline 2. & $\begin{array}{c}\text { Pengungkapan yang berkaitan } \\
\text { dengan pendekatan terhadap } \\
\text { estimasi. }\end{array}$ & Yes & Yes & $\begin{array}{c}\text { Halaman } \\
766 \text { dalam } \\
\text { paragraf } 129\end{array}$ \\
\hline 3. & $\begin{array}{c}\text { Pemisahan bagian goodwill ke } \\
\text { CGU. }\end{array}$ & Yes & Yes & $\begin{array}{c}\text { Halaman } \\
760 \text { dalam } \\
\text { paragraf } 80\end{array}$ \\
\hline 4. & $\begin{array}{c}\text { Semua goodwill yang } \\
\text { dialokasikan dengan jelas } \\
\text { terhadap CGU. }\end{array}$ & Yes & Yes & $\begin{array}{c}\text { Halaman } \\
760 \text { dalam } \\
\text { paragraf } 80\end{array}$ \\
\hline 5. & $\begin{array}{l}\text { Jumlah CGU yang lebih besar } \\
\text { dari atau sama dengan segmen } \\
\text { pelaporan primer. }\end{array}$ & Yes & Yes & $\begin{array}{c}\text { Halaman } \\
760 \text { dalam } \\
\text { paragraf } 80\end{array}$ \\
\hline 6. & $\begin{array}{c}\text { Metode penurunan nilai yang } \\
\text { telah diterapkan dan } \\
\text { diungkapkan. }\end{array}$ & Yes & Yes & $\begin{array}{c}\text { Halaman } \\
765 \text { dalam } \\
\text { paragraf } 129\end{array}$ \\
\hline 7. & $\begin{array}{l}\text { Metode yang dipakai untuk } \\
\text { menentukan nilai wajar } \\
\text { dikuragi biaya penjualan. }\end{array}$ & No & Yes & $\begin{array}{l}\text { Halaman } \\
765 \text { dalam } \\
\text { paragraf } 129 \\
\text { (i) }\end{array}$ \\
\hline 8. & $\begin{array}{l}\text { Metode tingkat diskonto yang } \\
\text { dipakai pada saat permodelan } \\
\text { arus kas yang diungkapkan. }\end{array}$ & Yes & No & $\begin{array}{l}\text { Halaman } \\
765 \text { dalam } \\
\text { paragraf } 129 \\
\text { (iv) }\end{array}$ \\
\hline 9. & $\begin{array}{l}\text { Pengungkapan mengenai } \\
\text { tingkat diskonto di CGU. }\end{array}$ & Yes & No & $\begin{array}{l}\text { Halaman } \\
765 \text { dalam } \\
\text { paragraf } 129 \\
\text { (iv) }\end{array}$ \\
\hline 10. & $\begin{array}{l}\text { Dasar penetapan tingkat } \\
\text { diskonto yang diungkapkan. }\end{array}$ & Yes & No & $\begin{array}{l}\text { Halaman } \\
764 \text { dalam } \\
\text { paragraf } 125\end{array}$ \\
\hline 11. & $\begin{array}{l}\text { Memakai tingkat diskonto } \\
\text { yang diungkapkan sebelum } \\
\text { pajak. }\end{array}$ & Yes & No & $\begin{array}{l}\text { Halaman } \\
753 \text { dalam } \\
\text { paragraf } 55\end{array}$ \\
\hline 12. & $\begin{array}{l}\text { Pengungkapan eksplisit } \\
\text { tingkat pertumbuhan yang } \\
\text { dipakai pada saat perkiraan } \\
\text { anggaran atau keuangan. }\end{array}$ & Yes & No & $\begin{array}{l}\text { Halaman } \\
765 \text { dalam } \\
\text { paragraf } \\
129 \text { (iii) }\end{array}$ \\
\hline 13. & $\begin{array}{lc}\text { Periode } & \text { yang } \\
\text { dipertimbangkan } & \text { bagi } \\
\text { permodelan arus kas. } & \end{array}$ & Yes & No & $\begin{array}{l}\text { Halaman } \\
765 \text { dalam } \\
\text { paragraf } \\
129 \text { (iii) }\end{array}$ \\
\hline
\end{tabular}




\begin{tabular}{|c|c|c|c|c|}
\hline 14. & $\begin{array}{l}\text { Pengungkapan eksplisit } \\
\text { perihal tingkat pertumbuhan. }\end{array}$ & Yes & No & $\begin{array}{l}\text { Halaman } \\
765 \text { dalam } \\
\text { paragraf } 129\end{array}$ \\
\hline 15. & $\begin{array}{l}\text { Jika prediksi periode melebihi } \\
\text { dari lima tahun, apakah } \\
\text { pembenaran itu diberikan?. }\end{array}$ & Yes & No & $\begin{array}{l}\text { Halaman } \\
765 \text { dalam } \\
\text { paragraf } 129 \\
\text { (iii) }\end{array}$ \\
\hline 16. & $\begin{array}{l}\text { Bila timbul penurunan } \\
\text { goodwill, apakah ini di } \\
\text { identidikasi ke dalam CGU } \\
\text { tersendiri? }\end{array}$ & Yes & Yes & $\begin{array}{l}\text { Halaman } \\
764 \text { dalam } \\
\text { paragraf } 125\end{array}$ \\
\hline 17. & $\begin{array}{l}\text { Apabila terdapat penurunan } \\
\text { goodwill, apakah hal ini } \\
\text { teridentifikasi dalam CGU } \\
\text { tertentu? }\end{array}$ & Yes & Yes & $\begin{array}{l}\text { Halaman } \\
764 \text { dalam } \\
\text { paragraf } 125\end{array}$ \\
\hline 18. & $\begin{array}{l}\text { Apabila terdapat penurunan } \\
\text { goodwill, apakah hal ini } \\
\text { teridentifikasi pada laporan } \\
\text { laba rugi? }\end{array}$ & Yes & Yes & $\begin{array}{l}\text { Halaman } \\
755 \text { dalam } \\
\text { paragraf } 60\end{array}$ \\
\hline
\end{tabular}

Sumber : Bepari dan Mollik (2015)

\section{Tipe Industri}

Tipe industri merupakan karateristik yang dimiliki oleh perusahaan yang berkaitan dengan risiko usaha, bidang usaha, lingkungan perusahaan dan karyawan yang dimiliki oleh perusahaan. Tipe industri dikelompokkan menjadi dua jenis yaitu industri manufaktur dan industri non manufaktur. Tipe industri yang berbeda memiliki kompleksitas operasional dalam laporan keuangannya. Kompleksitas timbul karena setiap industri memiliki informasi akuntansi yang berbeda sehingga masing-masing industri memiliki kelengkapan laporan keuangan yang berbeda. Mengacu pada penelitian Cooke (1989) pengukuran tipe industri menggunakan variabel dummy yaitu nilai 1 untuk perusahaan manufaktur dan nilai 0 untuk perusahaan non manufaktur.

\section{Ukuran Perusahaan}

Ukuran perusahaan adalah suatu ukuran yang dapat dikategorikan besar kecilnya suatu perusahaan dengan menghitung total aset, jumlah penjualan, total tenaga kerja atau jumlah pemegang saham, dan lain-lain yang dimiliki perusahaan (Cooke 1989). Dalam penelitian ini, ukuran perusahaan dalam penelitian ini diukur menggunakan total aset perusahaan

$$
S I Z E=\text { LN Total Aset }
$$

\section{Intensitas Goodwill Perusahaan}

Intensitas goodwill adalah besar kecilnya persentase goodwill yang terdapat di dalam suatu perusahaan. Menurut Bepari, Rahman, dan Mollik (2014) saat perusahaan mempunyai tingkat intensitas goodwill yang tinggi maka perusahaan tersebut akan lebih patuh pada pengungkapan dalam laporan keuangan dibandingkan perusahaan yang mempunyai tingkat intesitas goodwill rendah. Variabel intensitas goodwill diukur dengan goodwill perusahaan yang dibagi dengan total aset, dikali persentase $100 \%$.

$$
\text { INTENSGW }=\frac{\text { Goodwill }}{\text { Total Aset }} \times 100 \%
$$




\section{Latar Belakang Komite Audit}

Latar belakang komite audit merupakan pemahaman atau pengetahuan seorang anggota komite audit tentang akuntansi atau keuangan yang berlaku dalam perusahaan. Peranan komite audit sangat penting dalam membentuk tata kelola perusahaan yang baik. Komite audit mampu berperan sebagai penghubung antara manajemen dan auditor dan juga berperan mengawasi pelaksanaan tugas yang berhubungan dengan pembuatan laporan keuangan. Latar belakang komite audit yang mengerti akuntansi atau keuangan sangat diperlukan di dalam suatu perusahaan. Varibel latar belakang komite audit diukur menggunakan proporsi dengan rumus berikut ini:

$$
\text { LBKA }=\frac{\text { Jumlah Komite Audit Latar Belakang Akuntansi atau Keuangan }}{\text { Total Komite Audit }}
$$

\section{Kualitas Auditor}

Dalam penelitian ini, kualitas auditor diukur dengan memakai variabel dummy. Nilai 1 untuk perusahaan yang menggunakan auditor Big 4 dan nilai 0 untuk perusahaan yang menggunakan auditor non-Big 4.

Kantor akuntan publik (KAP) di Indonesia yang berafiliasi dengan Big 4 adalah : 1) KAP Purwantono, Sarwoko, Sandjaja - berafiliasi dengan Ernst - Young. 2) KAP Osman Bing Satrio - berafiliasi dengan Deloitte. 3) KAP Sidharta, Sidharta, Widjaja - berafiliasi dengan KPMG. 4) KAP Haryanto Sahari - berafiliasi dengan PwC

\section{Variabel Kontrol}

Penelitian ini menambahkan variabel kontrol yakni profitabilitas dan leverage. Profitabilitas merupakan kemampuan perusahaan dalam memperoleh laba atau profit. Profitabilitas diukur menggunakan return on assets (ROA). Return on assets adalah tingkat pengembalian aset perusahaan yang berfungsi untuk mengukur profitabilitas perusahaan. Semakin tinggi nilai ROA akan menentukan bahwa kemampuan perusahaan semakin baik. Pengukuran return on assets (ROA) menggunakan laba bersih perusahaan yang dibagi total aset perusahaan.

$$
\text { ROA }=\frac{\text { Laba Bersih Perusahaan }}{\text { Total Aset Perusahaan }} \times 100 \%
$$

Leverage bisa didefinisikan sebagai tingkat ketergantungan perusahaan terhadap hutang dalam membayar aset perusahaan maupun kegiatan operasi perusahaan. Leverage juga bisa diartikan kemampuan perusahaan dalam menggunakan dana atau aktiva yang memiliki beban tetap (fixed cost assets or funds) untuk memperbesar tingkat penghasilan (return) bagi pemiliki perusahaan. Dalam penelitian ini, pengukuran variabel leverage menggunakan hutang dibagi aset perusahaan.

$$
\mathrm{LEV}=\frac{\text { Hutang }}{\text { Aset Perusahaan }} \times 100 \%
$$

\section{Model Pengujian Hipotesis}

Pengujian hipotesis pada penelitian ini menggunakan analisis regresi berganda dikarenakan variabel yang digunakan lebih dari satu. Analisis regresi berganda adalah analisis yang berfungsi untuk mengukur kekuatan hubungan antara dua variabel atau lebih dan memberikan arah hubungan antara variabel dependen (Y) dengan beberapa variabel independen $(\mathrm{X})$. Model persamaan regresi yang tedapat pada penelitian ini antara lain:

$$
\begin{aligned}
\mathrm{GwImprt}= & \beta 0+\beta 1(\text { Tipe_Ind })+\beta 2 \text { (Auditor) }+\beta 3(\text { LbKA })+ \\
& \beta 4(\text { IntensGW })+\beta 5(\text { Size })+\beta 6(\mathrm{ROA})+\beta 6(\text { Lev })+\mathrm{e}
\end{aligned}
$$




\begin{tabular}{|c|c|c|}
\hline \multicolumn{3}{|c|}{ Keterangan: } \\
\hline GwImprt & $=$ & $\begin{array}{l}\text { Pengungkapan goodwill impairment } \\
\text { testing }\end{array}$ \\
\hline Tipe_Ind & $=$ & Tipe Industri \\
\hline K_Auditor & $=$ & Kualitas Auditor \\
\hline LbKA & $=$ & Latar Belakang Komite \\
\hline IntensGW & $=$ & Intensitas goodwill. \\
\hline Size & $=$ & Log total aset. \\
\hline ROA & $=$ & Presentase laba bersih dibagi dengan total aset. \\
\hline Lev & $=$ & Presentase hutang dibagi dengan total aset. \\
\hline
\end{tabular}

\section{HASIL DAN PEMBAHASAN}

\section{Statistik Deskriptif}

Pada bagian ini akan dibahas mengenai pola distribusi variabel-variabel yang digunakan dalam penelitian ini yang disajikan dalam Tabel 3. Dari data awal berjumlah 436 sebanyak 150 observasi dihilangkan untuk menormalkan data. Sampel akhir menjadi 286 observasi.

Tabel 3. Statistik Deskriptif

\begin{tabular}{|l|c|c|c|c|c|}
\hline & $\mathrm{N}$ & Minimum & Maksimum & Rata-Rata & Deviasi Standar \\
\hline GwImprt & 286 & 0,06 & 0,67 & 0,22 & 0,17 \\
Tipe_Ind & 286 & 0,00 & 1,00 & 0,13 & 0,33 \\
K_Auditor & 286 & 0,00 & 1,00 & 0,38 & 0,49 \\
LbKA & 286 & 0,20 & 1,00 & 0,60 & 0,26 \\
IntensGW & 286 & 0,00 & 0,26 & 0,03 & 0,04 \\
Size & 286 & 26,48 & 34,72 & 29,55 & 1,57 \\
ROA & 286 & $-0,24$ & 0,45 & 0,06 & 0,09 \\
LEV & 286 & 0,00 & 1,19 & 0,45 & 0,24 \\
& & & & & \\
\hline
\end{tabular}

Sumber: Data Sekunder yang Diolah (2019)

Berdasarkan tabel di atas, dapat diketahui bahwa variabel kepatuhan goodwill impairment testing mempunyai nilai minimum sebesar 0,06 nilai maksimal sebesar 0,67 dan nilai rata-rata 0,22 serta deviasi standar sebesar 0,17 . Dalam penelitian ini rata -rata perusahaan yang mematuhi pengungkapan goodwill impairment testing sebesar 17\%. Hal ini menunjukkan bahwa kepatuhan pengungkapan goodwill impairment testing di sampel penelitian cenderung rendah.

Variabel tipe industri memiliki nilai rata-rata sebesar 0,13 dengan deviasi standar sebesar 0,33 dan nilai minimum sebesar 0,00 sedangkan nilai maksimal sebesar 1,00. Tipe industri dalam penelitian ini merupakan perusahaan non manufaktur sebesar $87 \%$ dan perusahaan manufaktur $13 \%$.

Variabel kualitas auditor memiliki nilai rata-rata sebesar 0,38 dengan deviasi standar sebesar 0,49 serta nilai minimumnya sebesar 0,00 yaitu dan nilai maksimal sebesar 1,00 
yaitu. Kualitas auditor dalam penelitian ini mempunyai arti bahwa mayoritas perusahaan diaudit auditor non-Big 4 yaitu sebesar $62 \%$ dan 38\% diaudit oleh auditor Big 4.

Variabel latar belakang komite audit mempunyai rata-rata sebesar 0,60 dengan deviasi standar sebesar 0,26 serta nilai minimum sebesar 0,20 dan nilai maksimal sebesar 1,00. Latar belakang komite audit pada penelitian ini menunjukkan bahwa mayoritas dalam suatu perusahaan mempunyai komite audit dengan latar belakang akuntansi atau keuangan lebih banyak dibandingkan dengan komite audit dengan latar belakang yang selain akuntansi atau keuangan sebesar 0,60 (60\%).

Variabel intensitas goodwill memiliki nilai minimum sebesar 0,00 dan nilai maksimal sebesar 0,26 serta nilai rata-rata sebesar 0,03 dan deviasi standar sebesar 0,04. Intensitas goodwill adalah besaran goodwill terhadap total aset pada suatu perusahaan. Jika dilihat dari nilai rata-rata intensitas goodwill pada perusahaan pada penelitian ini, cenderung cukup relatif rendah terhadap aset yaitu sebesar $0,03(3 \%)$.

Variabel ukuran perusahaan mempunyai nilai minimum sebesar 26,48 (RP 314.747.000.000), nilai maximum sebesar 34,74 (Rp 1.195.091.000.000.000) serta rata - rata sebesar 29,55 (Rp 6.805.278.000.000 dengan deviasi standar 1,57. Hal tersebut membuktikan bahwa ukuran perusahaan yang termasuk dalam penelitian ini bermacam - macam dari skala menengah hingga besar. Menurut Peraturan Otoritas Jasa Keuangan (POJK) perusahaan dinyatakan skala menengah atau sedang jika memiliki total aset lebih dari Rp 50.000.000.000 - Rp 250.000.000.000. Variabel profitabilitas perusahaan memiliki nilai minimum sebesar 0,24 dan nilai maksimal sebesar 0,45 serta rata-rata sebesar 0,06 deviasi standar sebesar 0,09. Dilihat dari nilai minimum dan maksimal menunjukkan bahwa profitabilitas perusahaan dipenelitian ini bervariasi dari yang kecil $(-0,24)$ hingga besar $(0,45)$. Variabel leverage memiliki nilai rata - rata sebesar 0,45 dengan deviasi standar sebesar 0,24 serta minimum sebesar 0,00 dan nilai maksimal sebesar 1,19. Leverage pada penelitian ini, mempunyai arti bahwa bervariasi dari rendah hingga tingi yaitu 0,00 (0\%) hingga 1,19 (119\%).

\section{Pengujian Hipotesis}

Setelah semua asumsi terpenuhi, maka berikutnya adalah melakukan pengujian hipotesis untuk mengetahui pengaruh variabel independen terhadap variabel dependen. Hasil pengujian hipotesis disajikan dalanm Tabel 4.

Tabel 4. Hasil Uji Hipotesis

\begin{tabular}{|c|c|c|c|c|c|c|}
\hline \multirow[t]{2}{*}{ Model } & \multicolumn{2}{|c|}{$\begin{array}{c}\text { Unstandardized } \\
\text { Coefficients }\end{array}$} & \multirow{2}{*}{\begin{tabular}{|c}
$\begin{array}{c}\text { Standardized } \\
\text { Coefficients }\end{array}$ \\
Beta \\
\end{tabular}} & \multirow[b]{2}{*}{$\mathbf{T}$} & \multirow[b]{2}{*}{ Sig. } & \multirow[t]{2}{*}{ Hasil } \\
\hline & B & Std. Error & & & & \\
\hline $1 \quad$ (Constant) & $-0,577$ & 0,114 & & $-5,071$ & 0,000 & \\
\hline Tipe_Ind & 0,086 & 0,018 & 0,171 & 4,788 & 0,000 & Diterima \\
\hline Size & 0,023 & 0,004 & 0,214 & 5,917 & 0,000 & Diterima \\
\hline LbKA & 0,024 & 0,021 & 0,038 & 1,133 & 0,258 & Ditolak \\
\hline IntensGW & 1,251 & 0,143 & 0,302 & 8,748 & 0,000 & Diterima \\
\hline K_Auditor & 0,202 & 0,013 & 0,588 & 15,217 & 0,000 & Diterima \\
\hline $\mathrm{ROA}$ & $-0,751$ & 0,069 & $-0,402$ & $-10,908$ & 0,000 & Diterima \\
\hline LEV & 0,073 & 0,024 & 0,104 & 2,983 & 0,003 & Diterima \\
\hline
\end{tabular}


Dari Tabel 4 diketahui p-value tipe industri (Tipe_Ind) sebesar 0,000 dengan nilai koefisien 0.086. Ini artinya tipe industri berpengaruh positif terhadap luas kepatuhan pengungkapan goodwill impairment testing. Jadi hipotesis pertama pada penelitian ini diterima. Untuk variabel kualitas auditor (K_Auditor), nilai $p$-value yang diperoleh sebesar 0,000 dengan nilai koefisien 0.202. Hasil ini menunjukkan bahwa kualitas auditor berpengaruh positif terhadap luas kepatuhan pengungkapan goodwill impairment testing. Jadi hipotesis kedua pada penelitian ini diterima. Untuk variabel latar belakang Komite Audit (LbKA), nilai $p$-value yang diperoleh sebesar 0,258 sehingga dapat disimpulkan bahwa latar belakang komite audit tidak berpengaruh terhadap luas kepatuhan pengungkapan goodwill impairment testing. Jadi hipotesis ketiga pada penelitian ini ditolak.

Dari Tabel 4 juga diketahui nilai p-value intensitas goodwill sebesar 0,000 dengan nilai koefisien beta 1.251. hasil ini menunjukkan bahwa intensitas goodwill berpengaruh positif terhadap luas kepatuhan pengungkapan goodwill impairment testing. Jadi hipotesis keempat pada penelitian ini diterima. Sementara untuk ukuran perusahaan (Size), nilai p-value yang didapatkan adalah 0,000 dengan koefisien 0.023. Ini mengindikasikan bahwa ukuran perusahaan berpengaruh positif terhadap luas kepatuhan pengungkapan goodwill impairment testing. Jadi hipotesis kelima pada penelitian ini diterima. Selain itu, variabel kontrol profitabilitas perusahaan (ROA) dan leverage memiliki nilai $p$-value masing-masing sebesar 0,000 dan 0,003. Ini berarti bahwa profitabilitas dan leverage berpengaruh terhadap kepatuhan pengungkapan goodwill impairment testing

\section{Pembahasan}

Berdasarkan hasil analisis, diketahui tipe industri berpengaruh positif terhadap luas kepatuhan pengungkapan goodwill impairment testing. Tipe industri merupakan karakteristik suatu perusahaan yang mempengaruhi dalam pengungkapan pelaporan keuangan. Cooke (1992) menyatakan bahwa luas pengungkapan dalam laporan tahunan mungkin tidak sama untuk semua sektor ekonomi. Perusahaan manufaktur lebih banyak melaporkan informasi dibandingkan dengan perusahaan lain, karena perusahaan manufaktur memiliki kompleksitas operasional yang berbeda dengan industri pada umumnya. Kompleksitas timbul karena setiap industri mengungkapkan informasi akuntansi secara berbeda sehingga masing - masing industri akan memiliki kelengkapan laporan keuangan yang berbeda. Adanya pengaruh tipe industri terhadap pengungkapan kepatuhan goodwill impairment testing mengindikasikan bahwa perusahaan manufaktur dan non manufaktur memiliki perbedaan dalam kompleksitas operasional pada laporan keuangan. Hasil ini konsisten dengan Cooke (1992) dan Bepari dan Mollik (2015) yang juga menemukan bukti bahwa tipe industri berpengaruh positif terhadap kepatuhan pengungkapan goodwill impairment testing.

Berdasarkan hasil analisis, diketahui bahwa ukuran perusahaan berpengaruh positif terhadap luas kepatuhan pengungkapan goodwill impairment testing. Jadi hipotesis kelima pada penelitian ini diterima. Perusahaan besar yang memiliki tingkat asimetri informasi yang rendah, diasumsikan memiliki karyawan dengan keterampilan cukup berpengalaman dalam menyusun laporan keuangan. Dibandingkan dengan perusahaan kecil, masyarakat menilai bahwa perusahaan besar memiliki pondasi organisasi yang cukup baik sehingga menghasilkan jumlah aset yang besar. Dengan memiliki pondasi organisasi yang cukup baik, perusahaan besar akan lebih patuh daripada perusahaan kecil dalam hal kepatuhan pengungkapan laporan keuangan, termasuk pengungkapan untuk goodwill impairment testing yang merupakan bagian dari laporan keuangan perusahaan. Perusahaan yang berukuran besar cenderung lebih banyak mengungkapkan bagian laporan keuangannya karena mereka memiliki lebih banyak informasi yang diungkapkan. Perusahaan besar akan lebih hati - hati dalam melakukan pengelolaan perusahaan karena perusahaan yang lebih besar diperhatikan oleh masyarakat dan pengguna laporan keuangan sehingga perusahaan akan melaporkan 
dengan akurat. Hasil ini sesuai dengan penelitian Cooke (1992) dan Godfrey dan Koh (2009) yang menemukan bahwa adanya hubungan positif signifikan antara ukuran perusahaan dengan tingkat pengungkapan goodwill impairment testing.

Berdasarkan hasil analisis diketahui latar belakang komite audit tidak berpengaruh terhadap luas kepatuhan pengungkapan goodwill impairment testing. Pembentukan komite audit sebagai salah satu komite khusus di dalam perusahaan yang berfungsi untuk mengoptimalkan pengawasan yang merupakan tanggung jawab dewan komisaris. Komite audit mempunyai tujuan untuk membantu Dewan Komisaris dalam memenuhi tanggung jawab dalam memberikan pengawasan secara menyeluruh.

Komite audit yang berpengalaman akuntansi atau keuangan dan berpengalam selain akuntansi memiliki tugas dan tujuan yang sama. Dalam melakukan wewenang, tugas dan tanggung jawab, komite audit dengan latar belakang akuntansi atau keuangan dan selain akuntansi akan tetap mematuhi standar akuntansi dan prinsip akuntansi. Ketika dirasa bahwa manajemen tidak mematuhi standar pengungkapan yang berlaku, komite audit dengan latar belakang akuntansi atau keuangan dan juga yang selain berlatar belakang akuntansi atau keuangan akan memberikan teguran atau pun punishment yang sama. Sehingga perbedaan latar belakang komite audit tidak mempengaruhi kepatuhan perusahaan dalam mengungkapkan goodwill impairment testing. Hasil temuan ini mendukung temuan Aryantisari (2018) yang juga menemukan bahwa latar belakang akuntansi atau keuagan yang dimiliki komite audit tidak berpengaruh terhadap kepatuhan goodwill impairment testing pada perusahaan yang terdaftar di BEI pada tahun 2012-2017.

Hasil pengujian juga menunjukkan bahwa intensitas goodwill berpengaruh positif terhadap luas kepatuhan pengungkapan goodwill impairment testing. Perusahaan yang memiliki intensitas goodwill yang cukup tinggi akan membuat perusahaan lebih berani untuk mengungkapkan goodwill impairment testing, karena kemungkinan terjadi kerugian penurunan nilai lebih besar dibandingkan perusahaan dengan intensitas goodwill yang rendah sangatlah kecil. Perusahaan tidak akan cemas ketika goodwill harus dialokasikan ke dalam cash generating unit (CGU) karena memiliki presentase atau intensitas goodwill yang cukup besar. Menurut Bepari dan Mollik (2015) perusahaan yang memiliki tingkat intensitas goodwill yang tinggi akan lebih patuh dalam pengungkapan goodwill impairment testing daripada perusahaan yang memiliki tingkat intensitas goodwill yang rendah. Hasil ini sesuai dengan penelitian yang dilakukan oleh Bepari et al., (2014) pada perusahaan-perusahaan di Australia mendapatkan hubungan positif antara tingkat kepatuhan perusahaan terhadap goodwill impairment testing dengan intensitas goodwill dan juga penelitian Petersen dan Plenborg (2010)memberi bukti bahwa intensitas goodwill berpengaruh positif terhadap kepatuhan IFRS goodwill impairment testing.

Berdasarkan hasil analisis juga diketahui bahwa kualitas auditor berpengaruh positif terhadap luas kepatuhan pengungkapan goodwill impairment testing. Pemilihan auditor Big 8 / 6 / 5 / 4 dapat mempengaruhi penyajian pengungkapan laporan keuangan yang sesuai dengan penerapan IFRS (Stokes dan Webster, 2009). Auditor Big-4 berusaha menjaga reputasinya sehingga berusaha untuk mendorong perusahaan mengungkapkan laporan keuangan sesuai dengan PSAK 48. Selain itu, auditor Big-4 menginginkan perusahaan untuk lebih transparan dan tidak ada yang disembunyikan dalam mengungkapkan goodwill impairment testing. Auditor Big-4 tidak ingin perusahaan menyembunyikan sesuatu hal yang jelas salah dan akan merugikan perusahaan itu sendiri. Sehingga, auditor Big-4 akan terus mendorong suatu perusahaan untuk lebih transparan dalam mengungkapkan goodwill impairment testing. Hasil ini konsisten dengan penelitian yang dilakukan oleh Bepari et al., (2014) yang memberi bukti bahwa perusahaan yang diaudit oleh auditor Big-4 lebih mematuhi goodwill impairment testing sesuai dengan IFRS dibandingkan dengan auditor non-Big 4. 


\section{KESIMPULAN DAN SARAN}

\section{Kesimpulan} berikut :

Berdasarkan pada hasil analisis yang telah dilakukan dapat ditarik kesimpulan sebagai

1. Terdapat pengaruh antara tipe industri dengan kepatuhan pengungkapan goodwill impairment testing secara positif signifikan. Artinya tipe industri yang berbeda memiliki kompeksitas operasionalnya berbeda. Hasil penelitian ini mendukung penelitian Cooke (1992) serta Bepari dan Mollik 2015

2. Terdapat pengaruh yang positif signifikan antara kualitas auditor dengan kepatuhan pengungkapan goodwill impairment testing pada perusahaan-perusahaan di Indonesia. Artinya pemilihan auditor Big-4 akan mendorong perusahaan untuk lebih transparan dalam mengungkapkan goodwill impairment testing. Hasil penelitian ini mendukung penelitian terdahulu dari Bepari, et.al., (2014) serta Bepari dan Mollik (2015).

3. Latar belakang komite audit tidak berpengaruh positif signifikan terhadap kepatuhan pengungkapan goodwill impairment testing pada perusahaan-perusahaan di Indonesia.

4. Terdapat pengaruh antara intensitas goodwill dengan kepatuhan pengungkapan goodwill impairment testing secara positif signifikan pada perusahaan-perusahaan di Indonesia. Artinya semakin tinggi intensitas goodwill maka, akan dapat meningkatkan kepatuhan dalam mengungkapkan goodwill impairment testing dalam suatu perusahaan. Hasil penelitian ini mendukung penelitian terdahulu dari Petersen dan Plenborg (2010) serta Bepari, et.al., (2014).

5. Ukuran perusahaan tidak berpengaruh positif signifikan terhadap kepatuhan pengungkapan goodwill impairment testing pada perusahaan-perusahaan di Indonesia.

6. Profitabilitas perusahaan berpengaruh terhadap kepatuhan pengungkapan goodwill impairment testing pada perusahaan-perusahaan di Indonesia.

7. Leverage berpengaruh terhadap kepatuhan pengungkapan goodwill impairment testing pada perusahaan-perusahaan di Indonesia.

\section{Saran}

Penelitian di masa mendatang dapat menambahkan variabel lain yang berhubungan dengan kepatuhan pengungkapan goodwill impairment testing, misalnya pergantian CEO. Kabir dan Rahman (2016) menjelaskan bahwa ketika masa jabatan CEO pertama habis, CEO kedua yang menggantikannya akan lebih patuh dalam mengungkapkan laporan keuangan termasuk goodwill impairment testing pada tahun pertama masa jabatan.

\section{DAFTAR PUSTAKA}

Aryantisari, Y. 2018. Skripsi Analisis Pengaruh Kualitas Auditor, Latar Belakang Komite Audit dan Karakteristik Perusahaan Terhadap Kepatuhan Pengungkapan Goodwill Impairment Testing Berdasarkan PSAK 48.

Beatty, A., dan Weber, J. 2006. Accounting discretion in fair value estimates: An examination of SFAS 142 goodwill impairments. USA : Journal of Accounting Research, 44(2), 257-288. 
Bepari, M. K., dan Mollik, A. T. 2015. Effect of Audit Quality and Accounting and Finance Backgrounds of Audit Committee Members on Firms' Compliance with IFRS for Goodwill Impairment Testing. Canada : Journal Of Apllied Accounting Research 10 (2):116-149.

Bepari, M. K., Rahman, S. F., dan Mollik, A. T. 2014. Firms' compliance with the disclosure requirements of IFRS for goodwill impairment testing: Effect of the global financial crisis and other firm characteristics. Journal of Accounting and Organizational Change. German : Journal of Accounting and Organizational Change 10 (1):116149.

Butar Butar, S. 2007. Modul Statistik dan Aplikasi SPSS. Universitas Katolik Soegijapranata, Semarang.

Cooke, T. E. 1989. Disclosure in the Corporate Annual Reports of Swedish Companies. United Kingdom : Accounting and Business Research. 19 (74):113-124.

Cooke, T. E. 1992. The Impact of Size, Stock Market Listing and Industry Type on Disclosure in the Annual Reports of Japanese Listed Corporations. United Kingdom : Accounting and Business Research. 22. (87):229-237.

DeAngelo, L. E. 1981. Auditor size and audit quality. Amsterdam : Journal of Accounting and Economics. 3.(5):183-199.

Estrini, D. 2013. Analisis Faktor - Faktor Yang Mempengaruhi Audit Delay. Indonesia : Journal of Accounting and Economics. 5. 8-9.

Francis, J. R., dan J. Khrishnan. 2002. Evidence on Auditor Risk-Management Strategies Before and After Tax Private Securities Litigation Reform Act of 1995. Asia-Pasific : Journal of Accounting and Economics. (9):135-157.

Godfrey, J. M., dan Koh, P. S. 2009. Goodwill impairment as a reflection of investment opportunities. Australia : Accounting and Finance, 7. (4):117-140.

Goodwin, J. 2003. The Relationship Between the Audit Committee and the Internal Audit Function: Evidence from Australia and New Zealand. Australia. International Journal of Auditing Int. J. Audit. 7. (4):263-278.

Hodgdon, C., R. H. Tondkar., A. Adhikari., dan D. W. Harless. 2009. Compliance with International Financial Reporting Standards and Auditor Choice: New Evidence on the Importance of the Statutory Audit. Amsterdam. International Journal of Accounting. 44. (1):33-55.

Indra, S. 2014. Pengaruh Mekanisme Corporate Governance Dan Ukuran Perusahaan. Indonesia : Journal Of Accounting. 
Juan, N. E., dan E. T. Wahyuni. 2012. Panduan Praktis Standar Akuntansi Keuangan. Edisi Kedua. Jakarta : Salemba Empat

Kabir, H., dan Rahman, A. 2016. The role of corporate governance in accounting discretion under IFRS: Goodwill impairment in Australia. Australia : Journal of Contemporary Accounting and Economics 12(3), 290-308.

Kurniasih, T., dan Sari, M. M. R. 2013. Pengaruh Return on Assets, Leverage , Corporate Governance, Ukuran Perusahaan Dan Kompensasi Rugi Fiskal Pada Tax Avoidance (The Effect of Return on Asset, Leverage, Corporate Governance, Company Size, and Fiscal Loss Compensation in Tax Avoidance). Indonesia : Buletin Studi Ekonomi 8. (1):58-66.

Luthfiyati, B. 2016. Pengaruh Ukuran KAP, Opini Audit, Pertumbuhan Perusahaan Klien, Pergantian Manajemen dan Ukuran Perusahaan Klien terhadap Pergantian Auditor. Indonesia : Jurnal of Accounting 2(2):52-65.

Marston, C. 2003. Financial reporting on the Internet by leading Japanese companies. United Kingdom : Corporate Communications: An International Journal 8. (1): 23-34.

Nunung Nuryani, I. S. 2014. Pelaporan Kerugian Penurunan Nilai Goodwill Serta Dampaknya Terhadap Nilai Perusahaan. Indonesia : Jurnal Riset Akuntansi Dan Keuangan Program Studi Akuntansi Fakultas Pendidikan Ekonomi Dan Bisnis Universitas Pendidikan Indonesia. 2. (3):508-524.

Petersen, C., dan Plenborg, T. (2010). How do firms implement impairment tests of goodwill?. Australia : Journal Of Accounting 46(4): 419-446.

Peraturan Otoritas Jasa Keuangan (POJK 04). Diakses pada 15 Juni 2018 dari https://www.ojk.go.id/id/regulasi/otoritas-jasa-keuangan/rancangan regulasi/Documents/Draft\%20RPOJK\%20IX.C.7.pdf

Sitorus, I. J. 2012. Analisis Peran Komite Audit Yang Efektif Dan Independensi Dewan Komisaris (Studi pada Badan Usaha Milik Negara yang Terdaftar pada Bursa Efek Indonesia). Indonesia : Journal Of Accounting. 662-668.

Sudarmadji, A. M., dan Sularto, L. 2007. Pengaruh Ukuran Perusahaan, Profitabilitas, Leverage, dan Tipe Kepemilikan Perusahaan Terhadap Luas Voluntary Disclosure Laporan Keuangan Tahunan. Indonesia : Proceeding PESAT(Psikologi, Ekonomi, Sastra, Arsitek \& Sipil)2:53-61.

Vermaelen, T. 1981. 1. Common Stock Repurchases and Market Signalling. Amsterdam : Journal of Financial Economics. 9: 39-183. 